\title{
Influence of Disturbances in the Process of Fuel Injection on the Working Processes in the Cylinder Diesel Engine
}

\author{
Željko Bulatović1 \\ Dragan Knežević \\ Miodrag Milicic ${ }^{1)}$
}

\begin{abstract}
Unevenness of working processes in diesel engine cylinders can happen for several reasons. The two most influential factors to this phenomenon, which are related to disturbances in the fuel injection process are: disturbances in terms of the current position (rotation angle) of the crankshaft when the fuel injection in one of the cylinders starts, so-called pre-injection angle, and disturbances in the quantity of fuel that is supplied to individual cylinders during one work cycle, the so-called cycle amounts of fuel. These disturbances are more prominent in classical, mechanical fuel injection systems (high-pressure pump, pump-injector, etc.), and very often can not be prevented during the out engine testing and the fuel injection system adjustments. The simulation of disturbances described under real operating conditions of diesel engines, and expanding the knowledge of their individual and joined impact on the working processes in cylinders, is not at all simple. However, today there are commercial software which have built-in modules based on the proven equations of thermodynamics, combustion theory and the theory of flow, which makes it possible to carry out these simulations by using a computer. One such software is AVL BOOST. The simulation results obtained using this and similar software can be more reliable than simulations in real conditions of the engine, because in the mechanical fuel injection system it is very difficult to quantify the degree of the disturbance which is to be simulated. The given results can be used to develop methods of identifying the impact of described disturbances on the mean indicated pressure of each cylinder, as well as the entire engine, a more accurate assessment of mechanical losses (degree of mechanical utility), etc.
\end{abstract}

Key words: IC engine, diesel engine, engine cylinder, working process, fuel injection, pre-injection angle, pressure measurement.

\section{Appendix - Notations}

$q(i) \quad$ - parameter

$f_{p p} \quad$ - factor of pressure changes

$p_{c i l} p$ - pressure in cylinder with disturbances in the injection process

$p_{c i l} \quad$ - pressure in cylinder without disturbances in the injection process

$p_{i} \quad$ - mean indicated pressure in the cylinder

$p_{\max } \quad$ - maximum gas pressure in the cylinder

$T D C$ - top dead center

$\alpha \quad$ - angle of rotation crankshaft

\section{Introduction}

$\mathrm{D}$ URING the testing of the prototype for turbo charged diesel motors for special purposes, tag V46-X, with twelve cylinders in a V arrangement, equipped with highpressure pumps with a mechanical regulation with nominal power of $882 \mathrm{~kW}$ at $2000 \mathrm{rpm}$, the phenomena that might be associated with the assumption that the unevenness of working processes per cylinder is unexpectedly large had been observed. In support of this assumption, there is a sequence of structural particularities of the tested engine: long crankshaft $(1290 \mathrm{~mm})$, which acts as a highly elastic element, the existence of elastic elements (shafts) in operation with high pressure pumps, high pressure pipes of different lengths, short intake and exhaust channels whose geometry could not be optimized, etc.

Pressure curve measured in one of the engine cylinders, helped the further analysis using the AVL BOOST commercial software. Bearing in mind the required accuracy in determining top dead center (TDC) of measured pressure curve along the common experimental data given in $[1,12]$ and the data obtained by the method created in the procedure described in $[2,12]$. For determining the "zero line" (offset) the method of "referencing the two points" [3] has been used, as it gave the best results.

AVL BOOST software is, in fact, a "zero-dimensional" mathematical model of the working process. "The zerodimensional" mathematical model of the working process is based on the equations of thermodynamics, combustion theory and the theory of fluid flow, and is described in more details in references [4-6]. Independent execution of a validated mathematical model of the process would require an extensive software in work and preparation (specification of geometry intake and exhaust system, turbocharging, valve stroke rate, etc.) [4-6]. All this is avoided by using AVL BOOST software according to the provided instructions [7],

\footnotetext{
1) Military Technical Institute (VTI), Ratka Resanovića 1, 11132 Belgrade, SERBIA

2) University of Belgrade, Faculty of Mechanical Engineering, Kraljice Marije 16, 11020 Belgrade 35, SERBIA

Correspondence to: Željko Bulatović; e-mail:zetonbulat@gmail.com
} 
having previously prepared the necessary input data. In the process of modeling, the work of turbines and compressors has not been taken into account, instead the measured values of average pressure in the intake and exhaust manifold were used. Rest of the process: intake (related to the increased pressure in the intake manifold), exhaust (into the area of the exhaust manifold), elevation of the valve, heat transfer in the cylinder, the properties of gases and fuel, could be modeled quite realistically. Combustion process is modeled by the double Vibe function [4-6], where the necessary parameters are specified so as to obtain a good agreement with the measured pressure (Fig.1). The achieved degree of agreement is explained by the fact that mean indicated pressure of real and simulated process in the cylinder does not differ by more than $1.8 \%$.

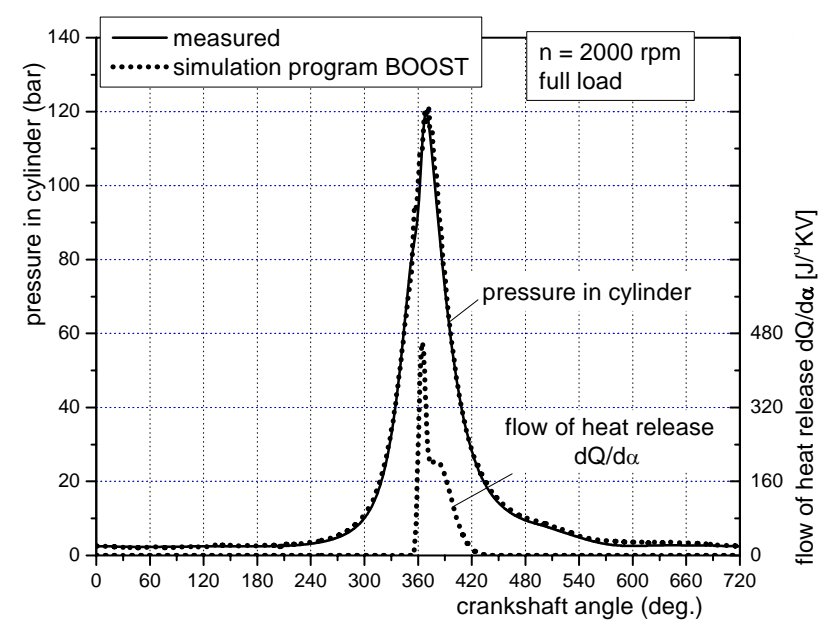

Figure 1. The measured pressure flow and pressure flow together with the heat release during simulated AVL BOOST software at $2000 \mathrm{rpm}$ and full load

By varying the values of the two most important parameters of the injection process: pre-injection angle $\left(\alpha_{p i}\right)$ and cycle amount of fuel, using AVL BOOST, it was possible to quite realistically determine their influence on the engine working process. The influence of the pre-injection angle is generally rough and insufficiently precise in textbooks and professional literature [7] (Fig.2). In this figure, the curve marked with 1 corresponds to quite small values of preinjection angle $\alpha_{p i 1}$, curve 2 corresponds to the optimal preinjection angle $\alpha_{p i 2}$, while the curve 3 corresponds to a higher than optimal pre-injection angle $\alpha_{p i 3}$.

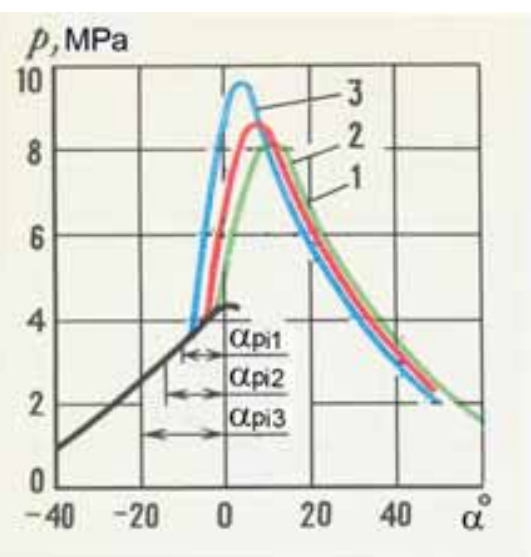

Figure 2. Rough way of showing principled dependencies of the pressure flow on pre-injection angle, i.e. of the start of injection $\left(\alpha_{p i}\right)$ in the cylinder of diesel engines [7]
By comparing the pressure curves, with or without disturbances described in the injection process obtained using such a simulation, conditions for gaining quite a realistic insight about their real impacts on the engine working process have been made. This makes it possible to set the criteria for corrections of measured reference pressure flows, in order to develop methods in which by monitoring the flow of torque to the crankshaft output or the flow of angular speed of the crankshaft [10], we obtain information about the working processes in engine cylinders in which indicating of pressure is not done.

In this paper, the analysis of influence of the factors which could lead to unevenness in working processes per cylinder of diesel-engine V46-X prototype, which can apply to any other diesel engine, is provided. After that, the AVL BOOST software has been used to simulate the influence of major disturbances in the working process on the fuel injection process. This simulation is used to set the criteria for developing identification methods for the influence of the working process disturbances on the fuel injection process.

\section{Results of the analysis of the most influential factors which can lead to unevenness of working processes per engine cylinders}

In an attempt to give the physical meaning and explanation to the assumption about unevenness of working processes of the prototype engine V46-X cylinders, we must carry out a more detailed analysis of the factors which could affect the unevenness of workflows per cylinder that arise from the structural specificity of the tested engine. As the most influential factors which can lead to imbalances of the workflow in the tested engine cylinder, the following can be considered:

1. Different conditions of the air flow compressed in the turbocharger from the intake manifold into individual cylinders of the engine. Propagation of airpressure waves compressed in the turbocharger can significantly affect the differences in local coefficients of air per cylinder, if optimization of the intake pipes is not carried out.

2. As at the inlet, it is logical to expect that there are different conditions of flow of the combustion products from the engine cylinders into the exhaust manifolds. Depending on the real conditions of flow of the combustion products from the engine cylinders, there may be differences in the coefficients of filling cylinders or differences in operation of the right or of the left turbocharger, which in turn can lead to completely different effects on the intake of the engine.

3. Different conditions of pressure wave propagation in high pressure pipes due to their different lengths. The range of length of the pressure pipe in the prototype engine V46-X is from $425 \mathrm{~mm}$ to $675 \mathrm{~mm}$. Figures 3-5 side by side display measured data at test bench $\mathrm{BOSCH}$ for the following sizes of the longest and shortest pipe in the engine: pressure flow at the beginning and the end of the high-pressure pipe and needle injector lift. In doing so, in both cases the same elements of the fuel injection system are used, with the exception of the high pressure pipes, which were of varying lengths. All curves are synchronized and expressed in crankshaft rotation angle domain, while the abscissa is not associated with the engine workflow. Absolute values of the parameters measured by the 
ordinates are not given, because they are of no importance for this analysis. Flows of pressure of work fluid at the start of pipeline for the longest and the shortest high-pressure pipe vary somewhat in the areas of maximum values, but do not show a more important phase difference (Fig.3), which is quite logical.

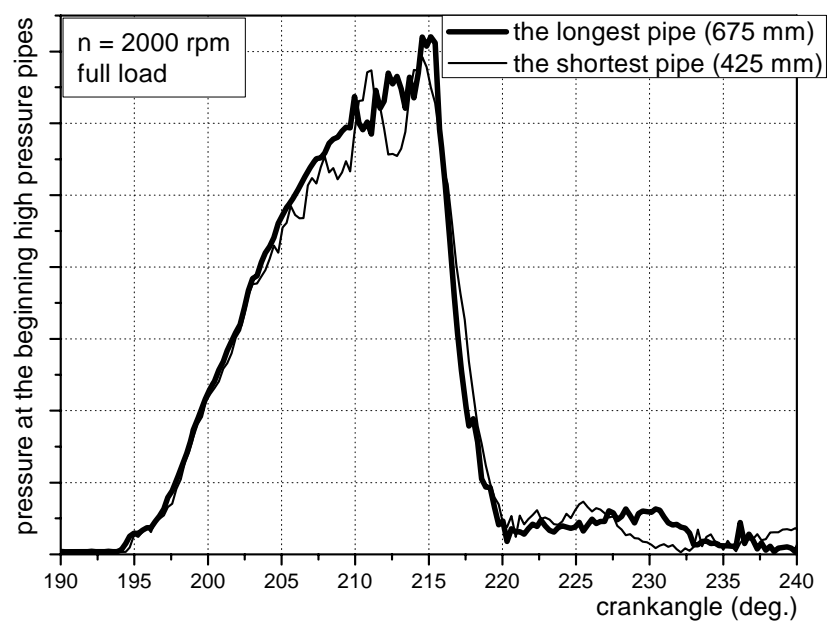

Figure 3. The pressures at the start of pipeline for the longest and the shortest high pressure pipe

However, the phase difference of pressure flows of the work fluid at the ends of the longest and shortest high pressure pipe was observed (Fig.4). The result is that the injector needle in the shortest pipe begins to raise much earlier than for the longest pipe, as much as 2.3 degrees calculated at the rotation angle of the engine crankshaft (Fig.5).

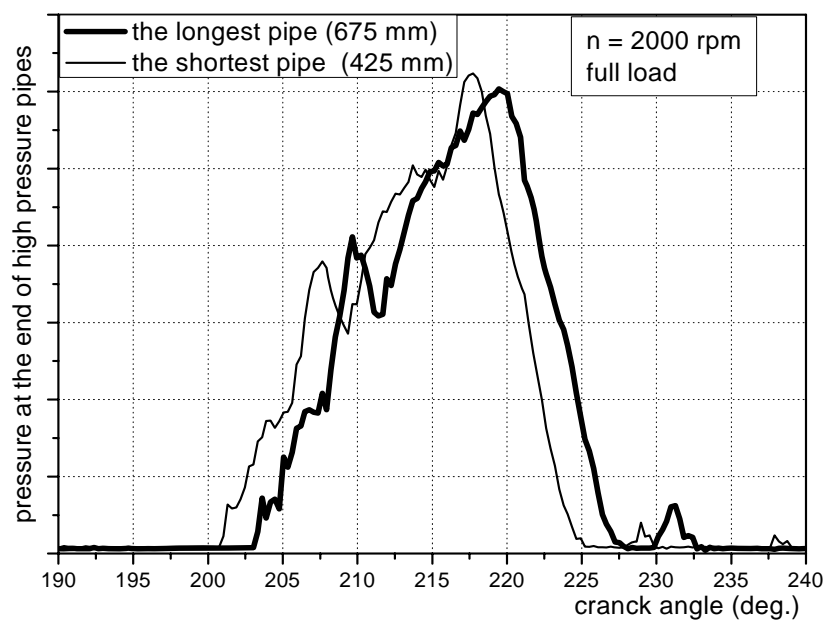

Figure 4. The pressures at the end of of pipeline for the longest and the shortest high pressure pipe

Processes which are carried out during the fuel injection within the pump-pipe high-pressure injector system have an extremely complicated dynamic character, where the velocity of the work fluid and the generated pressure pulses are different categories, which are transmitted in accordance with the laws of wave motion [9].

The influence of the pipe length on the fuel injection process, from the hydraulic-dynamic point of view, is very complex [9]. It is important to emphasize that in this case, registered differences in dynamic pre-injection angle are 2.3 degrees per crankshaft rotation angle, because of the difference of $250 \mathrm{~mm}$ in pipe lengths. Using a simple calculation we see that the speed of sound, i.e. the speed of propagation of wave pressure in these studies, was approximately $1304 \mathrm{~m} / \mathrm{s}$. Since this value is less than the average speed of sound through the mediums on the basis of oil and its derivatives (about $1500 \mathrm{~m} / \mathrm{s}$ ), it can be concluded that in its installation next to fuel, gas phase was present, which led to a drop in the speed of sound. Experimental studies show that in real conditions the presence of such quantities of gas phase mixed with the liquid fuel is possible and leads to a drop in the speed of sound up to $500 \mathrm{~m} / \mathrm{s}[5,9]$. In this case, the difference in dynamic pre-injection angle instead of 2.3 degrees per crankshaft rotation angle (Fig.5), amounted to about 6 degrees.

4. Unevenness in the cycle amount of fuel which highpressure pump delivers to individual cylinders. This occurs for two main reasons. The first reason is that it is simply impossible to make a perfect equalization of the cycle amount of fuel which individual elements of the high pressure pump are supposed to deliver to appropriate cylinders, thus there are always few percent deviations which can be tolerated. The second, much more influential reason, lies in the fact that due to the existence of elastic elements (primarily shafts) in the camshaft drive of high pressure pumps, angular speed of the camshaft is variable. Decreasing flow of angular velocity of the high pressure camshaft pump during the fuel injection in some of the cylinders implies a longer duration of injection and greater quantity of injected fuel [9]. In the opposite case, some of the engine cylinders get a smaller quantity of injected fuel from the one that is set during testing, with the rigid camshaft drive of the high pressure pump. The tests described in [9] show that variations in the cycle amount of fuel for the above described two extreme cases, can vary over $\pm 10 \%$ compared to the value set on the BOSCH bench when out motor testing high-pressure pumps.

5. And finally, twisting the crankshaft can lead to deviations in pre-injection angles of requirements that seek to meet the adopted order of ignition. Looking at V46-X engine, measured relative twisting of the one end of the crankshaft in relation to the other end, in some regimes exceeds 2.5 degrees [10].

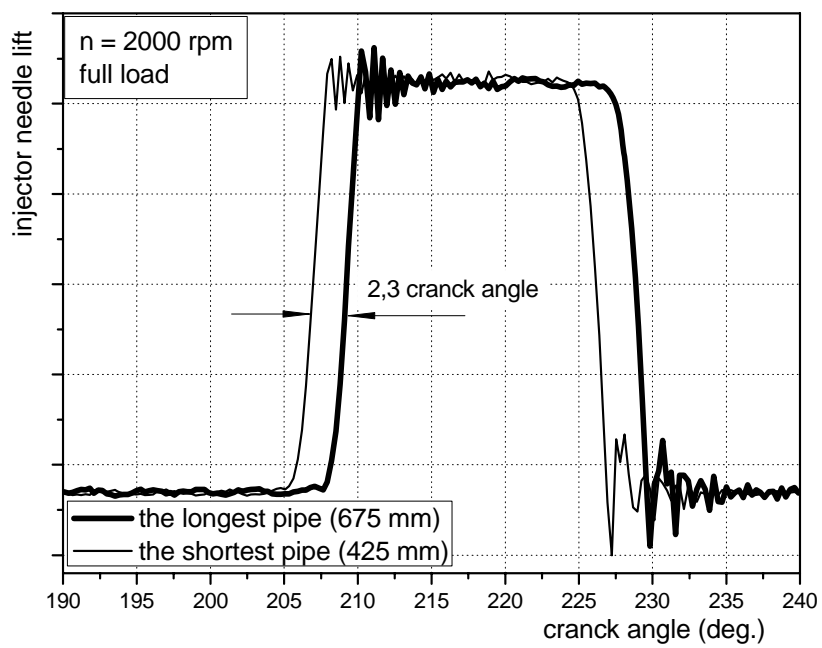

Figure 5. Injector needle lift for the longest and the shortest high pressure pipe

This analysis clearly indicates that out of all listed factors which could affect the unevenness of working processes by cylinders as primary influential are distinguished variations in pre-injection angle and uneven cycle amount of fuel which enters engine cylinders. 


\section{Results of the analysis of influence of type of disturbance in the fuel injection process on the working process by using AVL BOOST software}

When varying the pre-injection angle, parameters of the Vibe function are unchanged which describes bringing of heat during combustion, which is not quite correct. In reality, probably at the previous injection, the period of latent combustion increases while increasing the share of uncontrolled combustion processes, and vice versa. However, the Vibe function parameter changes in this case may not be so pronounced as to prevent solid assessment about what happens to the working process when it comes to the described disturbances during the fuel injection.

All the analyses that follow refer to the results of simulations using the AVL BOOST software, where the base curve of pressure, which is assumed to represent a regular work cycle without disturbances in the process of injection, is presented in Fig. 1 using dots.

The initial analysis was based on a simulation of somewhat larger but realistically possible disturbance in the pre-injection angle, and the slightly smaller disturbance in the cycle amount of fuel, in order to obtain an approximate representation of the effects and the specifics of their impact on the engine working process. The following variants are simulated:

1. The pre-injection angle, in one case, increased by 6 degrees per crankshaft rotation angle, and then decreased by 6 degrees per crankshaft rotation angle. The results of this simulation are shown in Fig.6, and it can be concluded that this kind of disturbance leads to visual deviations in pressure curve flow which can be seen visually. The changes are particularly intense in the immediate vicinity before and after top dead center, while being harder to spot deeper in expansion stroke.

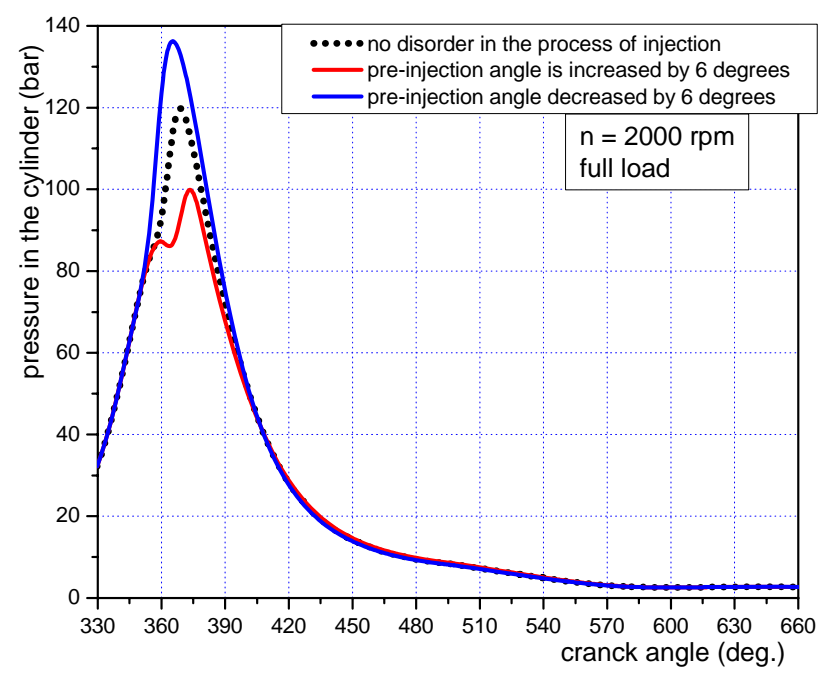

Figure 6. The influence of deviations in the cycle amount of fuel of +6 and $6 \%$ on the flow of pressure in cylinder simulated using AVL BOOST, at 2000 rps and full load

2. The cycle amount of fuel in one case increased by $6 \%$, and then decreased by $6 \%$ compared to the average value measured during the experiment, and that served as an input in the AVL BOOST software. The results of this simulation are shown in Fig.7 and, at first glance, it can be concluded that this kind of disturbance leads to deviations in the pressure curve flow which cannot be so easily registered by visual inspection, as in the previous case. Mild enough changes in the form of irregular offset are also present during the phase of the regular combustion and expansion throughout the stroke.

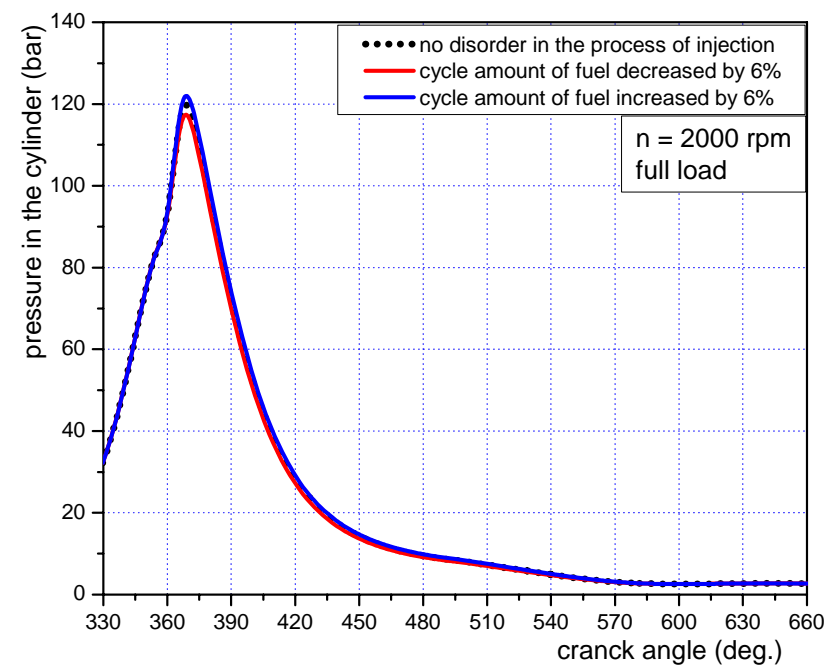

Figure 7. Cumulative influence of increase in the cycle amount of fuel by $6 \%$ and decrease in the pre-injection angle by 6 degrees on the pressure flow in the cylinder simulated using AVL BOOST, at 2000 rps and full load

3. The cycle amount of fuel increased by $6 \%$, and preinjection angle simultaneously decreased by 6 degrees per crankshaft rotation angle. The results of this simulation shown in Fig. 8 were intended to draw attention to a realistic possibility of a greater contribution of cylinders to the overall torque of gas forces caused by hardly predictable collective influence of disturbances in the fuel injection process. The cycle amount of fuel could be increased by more than $6 \%$, as that case is realisically very possible, but not beyond reasonable limits of limited excess air ratio, in order to avoid a situation where a rich mixture of fuel and air which cannot burn a whole is simulated. For this reason, the upper limit of the cycle amount of fuel during simulation using AVL BOOST has not exceeded an increase of $10 \%$, which means that even with an increase in the cycle amount of fuel above $10 \%$ of the mixture would not have burned regularly. On the other hand, the lower limits in reducing the cycle amount of fuel in this simulation could be higher than the maximum of set $20 \%$, since such a situation without any restrictions is realistically quite possible.

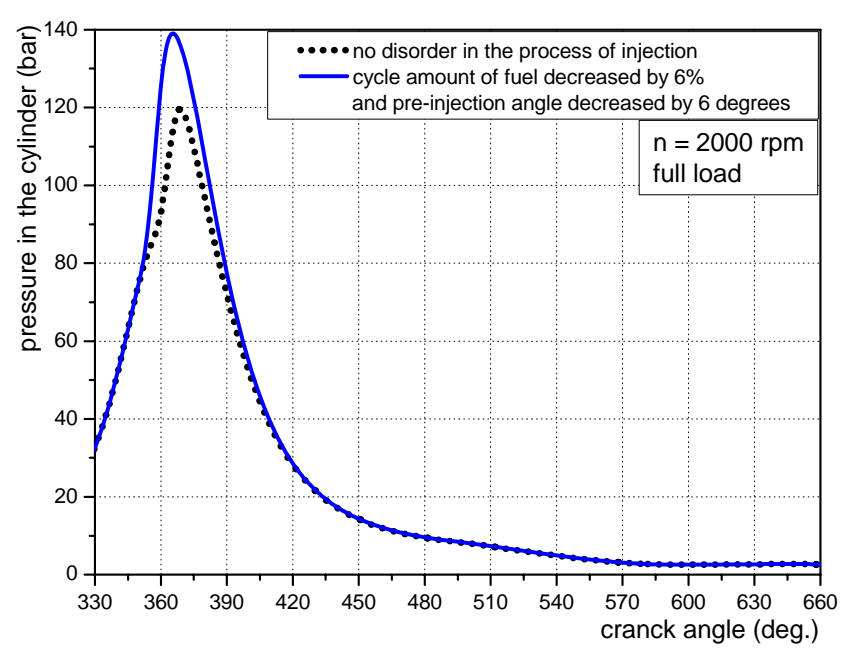

Figure 8. Cumulative influence of increase in the cycle amount of fuel by $6 \%$ and decrease in the pre-injection angle by 6 degrees on the pressure flow in the cylinder simulated using AVL BOOST, at $2000 \mathrm{rps}$ and full load 
Summarized results of the analysis of all simulated variants of disturbances in the fuel injection process are given in Table 1, where as indicators of the effects of these disturbances serve the obtained values of mean indicated pressure $\left(p_{i}\right)$ and maximum gas pressure in the cylinder $\left(p_{\max }\right)$. The two most important conclusions are:

1. Shifting the pre-injection angle significantly influences the maximum pressure, but significantly less the mean indicated pressure compared to variations in the cycle amount of fuel.

2. Variations in the cycle amount of fuel have a different effect, slightly on the maximum pressure, but more significantly on the mean indicated pressure, nearly as much as the percentage change in the cycle amount of fuel (about 5.5\% when changing the cycle amount of fuel by $6 \%$ ).

This raises the question of how to most appropriately use the results of this analysis in developing assessment methods of the contribution of each cylinder to the total torque of the engine. The first thing which comes to mind in this direction is to seek the pressure flow quotient obtained by simulating above-described various types of disturbances in the injection process $\left(p_{c i l}^{p}\right)$ and the base curve which is assumed to represent the cycle with optimal, undisturbed injection parameters $\left(p_{c i l}\right)$. This quotient is obviously not a constant but a variable function which could be called a factor of pressure changes $\left(f_{p p}\right)$ defined by the term:

$$
f_{p p}=\frac{p_{c i l}^{p}}{p_{c i l}}
$$

Figures 9-11 show the flows of pressure change factors for all variants of disturbances in the injection process analyzed using AVL BOOST software, at the engine speed $2000 \mathrm{rpm}$ and full load, as follows:

- Fig.9 presents the factor of pressure changes at deviations in pre-injection angle by +6 degrees (red curve) and -6 degrees (blue curve),

- Fig. 10 presents the factor of pressure changes at deviations in the cycle amount of fuel by $+6 \%$ (blue curve) and $-6 \%$ (red curve),

- Fig.11 presents the factor of pressure changes in the simultaneous deviations in the cycle amount of fuel by $+6 \%$ and pre-injection angle by -6 degrees.

Flows of pressure change factors for different types of simulated disturbances in the injection process shown in Figures 9-11 indicate that it would not be impossible for one parameter to approximate each simulated disturbance individually, but it is simply impossible to set universal unique criteria for all types of simulated but realistically quite possible disturbances.

However, all of them share one trait, which is that at angular domain of the crankshaft rotation angle of 360 degrees, in some cases before 360 degrees, up to 600 degrees, or slightly less than 600 degrees, the function $f_{p p}$ has a fluctuating flow, while at the rest of its domain it is constant and effectively equal to one.

More variants were analyzed, this time with more extreme disturbances in the fuel injection process, which in real terms were possible and which could be related to the large discrepancies in the contributions of individual engine cylinders to the total torque.

The approximate estimate based on the measured air flow through the engine intake system and the calculated excess air ratio indicates that this limit should not be larger than about $+30 \%$ compared to the referential, indicated cylinder, provided that the referential cylinder is in fact a cylinder in which deviations in injection parameters are not largely present, as assumed at the beginning of this analysis.

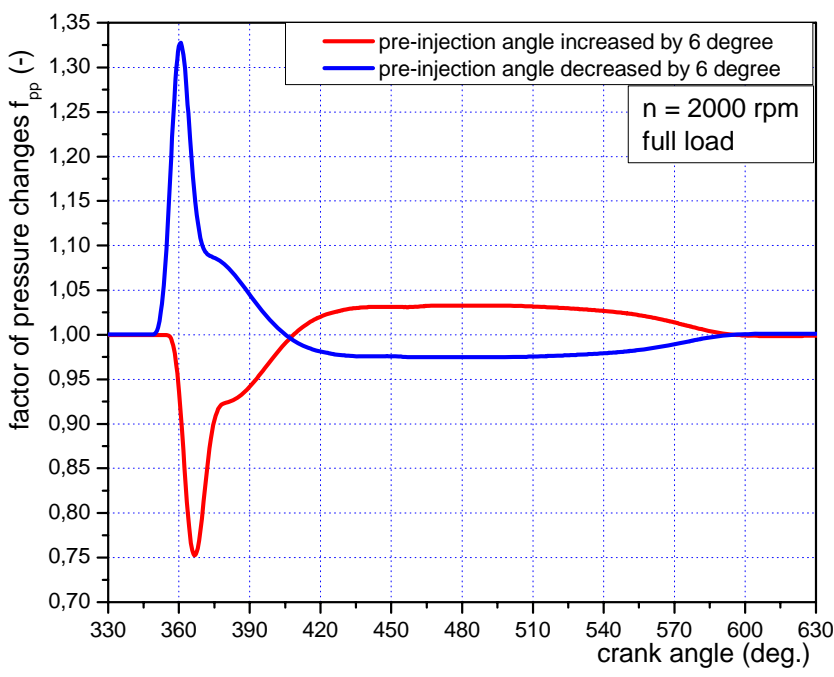

Figure 9. Factors of pressure changes with deviations in pre-injection angle by +6 and -6 degrees simulated using AVL BOOST software, at $2000 \mathrm{rps}$ and full load

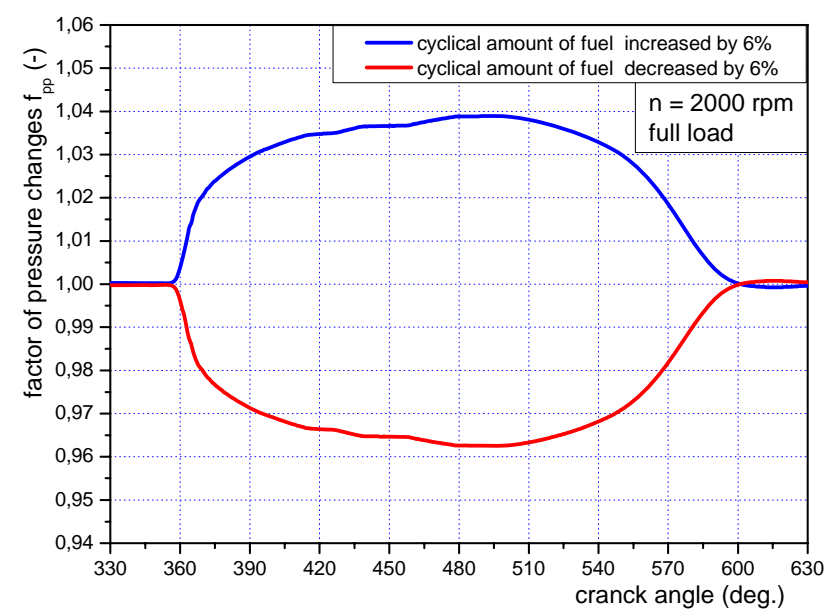

Figure 10. Factors of pressure changes in deviations in the cycle amount of fuel by +6 and $-6 \%$ simulated using AVL BOOST software, at $2000 \mathrm{rps}$ and full load

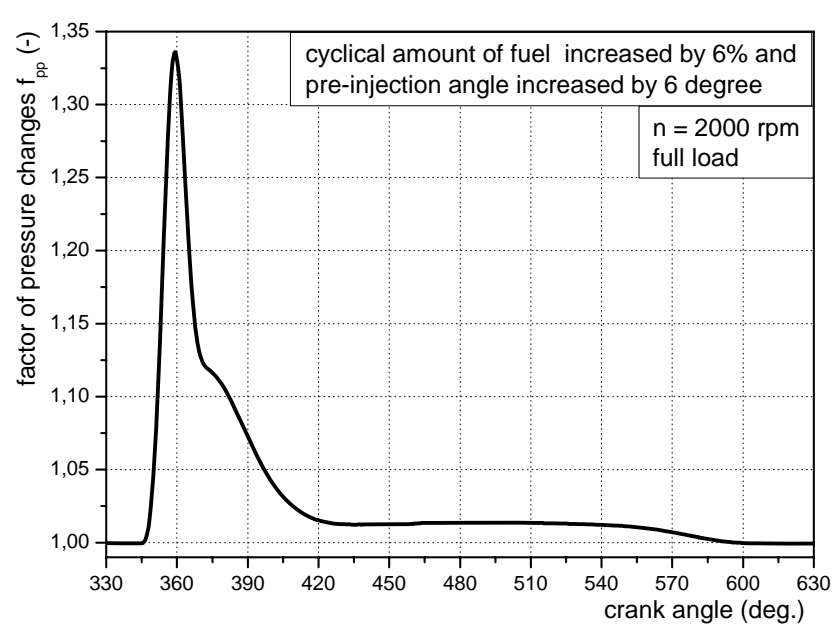

Figure 11. Factors of pressure changes in deviations in the cycle amount of fuel by $+6 \%$ and pre-injection angle by -6 degrees simulated using AVL BOOST software, at 2000 rps and full load 
Table 1. The effect of the type of disorder in the injection process on the mean indicated pressure $\left(p_{i}\right)$ and maximum gas pressure in the cylinder $\left(p_{\text {max }}\right)$

\begin{tabular}{|c|c|c|c|c|}
\hline \multirow[t]{2}{*}{$\begin{array}{l}\text { Type of disorder } \\
\text { in the process of injection }\end{array}$} & $p_{i}$ & $\begin{array}{l}\text { Percentage of } p_{i} \text { in } \\
\text { comparison to the case } \\
\text { with no disturbances }\end{array}$ & $p_{\max }$ & $\begin{array}{l}\text { Percentage of } p_{\max } \text { in comparison } \\
\text { to the case with no disturbances }\end{array}$ \\
\hline & bar & $\%$ & bar & $\%$ \\
\hline Without disturbance & 15,47 & 100 & 120 & 100 \\
\hline Pre-injection angle increased by 6 deg. & 14,77 & 95,47 & 100 & 83,33 \\
\hline Pre-injection angle decreased by 6 deg. & 15,95 & 103,10 & 136,25 & 113,54 \\
\hline Cycle amount of fuel increased by $6 \%$ & 16,33 & 105,56 & 122 & 101,67 \\
\hline Cycle amount of fuel decreased by $6 \%$ & 14,62 & 94,51 & 117,4 & 97,83 \\
\hline $\begin{array}{c}\text { Pre-injection angle increased by } 6 \mathrm{deg} \text {. and cycle amount of } \\
\text { fuel increased by } 6 \%\end{array}$ & 16,83 & 108,79 & 139 & 115,83 \\
\hline
\end{tabular}

However, many indicators show that the indicated cylinder does not represent the "optimal medium cylinder", so it is very possible that their working process, to a lesser or greater extent, is accompanied by disturbances in the injection system which are being analyzed, negatively affecting their effectiveness.

\section{Setting criteria for developing methods of identifying the effect of disruptions in the fuel injection process on the working process}

This very limited number of displayed results of the simulations of the influence of variations in the fuel injection on the working processes in the cylinders could be joined by such deviations of the cycle amounts of fuel which would result in an increase or decrease of middle torques of gas forces per cylinder, while at the same time, pre-injection angles have values which have quite an opposite affect, thus increasing the number of possible, quite different forms of factors for changes in pressure $\left(f_{p p}\right)$ increased to a very wide range. The attempt at installing a universal principle, which would include all possible forms of pressure change factors $\left(f_{p p}\right)$, is therefore futile. But, if the aim is set at striving to estimate a more realistic mean indicated pressure for each cylinder, which is directly proportional to the middle torque of gas forces, in which case such a target does not have to be impossible to realize. Comparing the flow of pressure change factors $\left(f_{p p}\right)$ only in case of increased or reduced cycle amount of fuel (eg, Fig.10), compared to the flows of this factor only in case of deviations in the the pre-injection angle (eg, Fig.9), it can be clearly concluded that curves in Fig. 10 can be more easily approximated by a relatively simple function rather than in the case with the curve shown in Fig.9.

In Fig. 12 it is practically shown that the factor of pressure changes $\left(f_{p p}\right)$ in case of simulations of increased cycle amount of fuel by $10 \%$, can quite easily be approximated using trapezoidal or rectangular shape of the approximate function. And, in both cases, the approximate functions are dependent only on one variable, which is exactly the function of the correction factors of pressure flow (gas torque force) which needs to be identified.

The effect of these approximations is shown in Fig.13, where the base pressure curve without disturbances in the injection process (pink curve), served for AVL BOOST software to simulate the increased cycle amount of fuel by $10 \%$ (black curve), followed by the same base curve being corrected using trapezoidal shape of the approximate function (red curve), and finally the base curve is corrected using rectangular shape of the approximate function (blue curve). Visually, it could be said that the deviations in the black, red and blue curve are very small, almost imperceptible, as evidenced by the resulting values of mean indicated pressure which did not differ by more than 0.15 bar.

In Fig. 12 it is clear that the trapezoidal shape approximation function more faithfully follows the curve factors of pressure changes $\left(f_{p p}\right)$, but this form of approximation is somewhat more complex as takes into account the angles which the large base of the trapezoid builds with prongs. The bigger problem is that these angles are not constant, instead changing for different values of disturbances in the cycle amount of fuel so, even with this principle of approximations, a universal rule for all possible deviations in the cycle amount of fuel cannot be set. From this, the rectangular shape of the approximate curve of the factors of pressure change as a spring board function in the angular domain of 370 to 570 degrees of crankshaft rotation angle:

$$
f(\alpha)=\left\{\begin{array}{c}
1, \alpha<370 \wedge \alpha>570 \\
q(i), 370 \leq \alpha \leq 570, i=1 \ldots 10
\end{array}\right.
$$

crystallized as optimal, simpler and more universal solution. This principle of approximation quite accurately describes the variations of working processes in one of the cylinders due to disruptions in the cycle amount of fuel, and values of the mean indicated pressure and pressure curve shape. For disturbances only in the pre-injection angle it can not be expected that the adopted method of correction will give good concurrence with the corrected and real pressure curve, but for the combined disturbances (pre-injection angle and cycle amount of fuel), somewhat of a better match between corrected and real pressure curves can be expected.

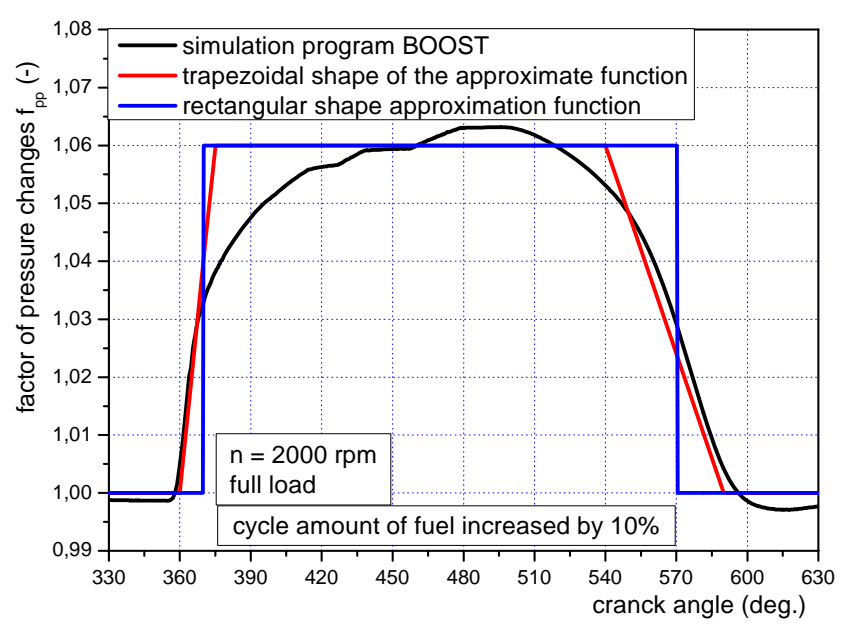

Figure 12. Approximation of the factors of pressure changes $\left(f_{p p}\right)$ in case of simulation of increased cycle amount of fuel by $10 \%$ by using AVL BOOST software using trapezoidal and rectangular shape of the approximate function (2000 rps, full load) 


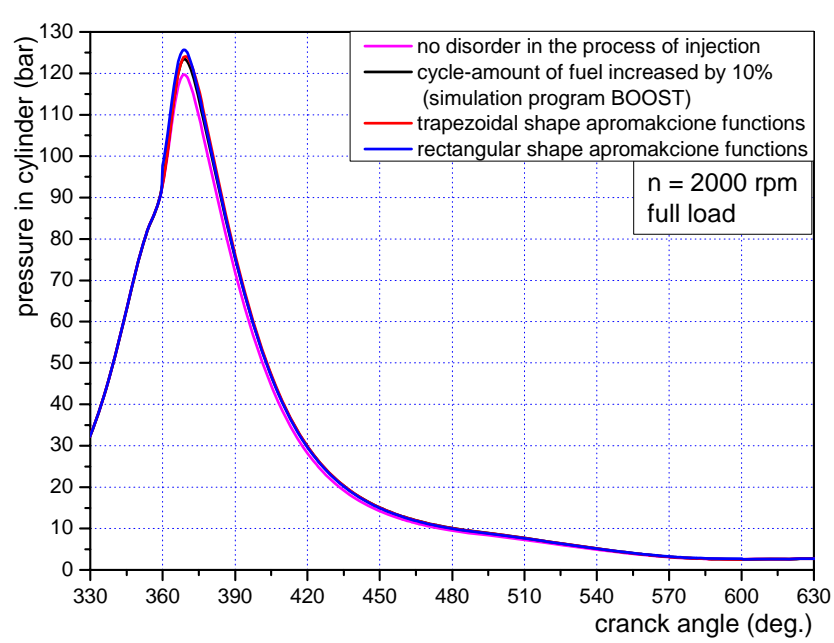

Figure 13. Changes in the pressure flow due to assumed increase in the cycle amount of fuel by $10 \%$ of the resulting AVL BOOST software simulation, using the trapezoidal shape of the approximate function and rectangular shape of the approximate function

\section{Conclusion}

The paper contains the analysis of the influence of two important parameters of the injection system (pre-injection angle and cycle amount of fuel) on the flow of working processes in cylinders of the tested diesel engines. For this analysis, AVL BOOST commercial software has been used, which is based on "zero-dimensional" mathematical model of the working process in the diesel engine cylinder. Despite some simplifications, resorted to while using AVL BOOST, it can be said that quite a realistic representation of this problem has been obtained. In the literature, this problem has been discussed quite superficially and coarsely because the real experiments, which should provide it, are very difficult to realize with a sufficient accuracy.

The AVL BOOST software allowed for crystallization of the two most important conclusions about the influence of disturbances in the process of fuel injection on the working processes in the engine cylinders, which are:

1. Varying the pre-injection angle significantly affects the maximum pressure, while less affecting the mean indicated pressure.

2. Variations in the cycle amount of fuel have a different effect, very little on the maximum pressure but significantly in the mean indicated pressure, that is nearly as much as the percentage change in the cycle amount of fuel.

On the other hand, previously given analyses show that the extreme variations in the cycle amounts of fuel are more likely than the extreme variations in the pre-injection angles. By adopting it practically without an alternative principle of correction of the pressure curve measured in the reference cylinder, created were the more realistic conditions of assessment of mean indicated pressure in cylinders which were not indicated.

The rectangular shape of the approximation curve of pressure change factors as a spring board function on a narrow angular domain after TDC (from 370 to 570 degrees of the crankshaft rotation angle), according to Equation (2), where it was adopted as an unknown parameter for nonindicated engine cylinders and optimized using the Marquard method [11], as a part of a robust mathematical model of the dynamics of the crankshaft of the aforementioned engine V46-X [10], effectively served to make quite accurate estimates of contributions of all cylinders of its total torque.

\section{References}

[1] HOHENBERG,G.: Definition und Eigenschaften des termodinamischen Verlust-winkels von Kolbenmaschinen, Automobil industrie, 1976, No.4, pp. 15-21, DK 621.43/512:621.1.016.7.

[2] TAZEROUT,M., O.Le CORRE, ROUSSEAU,S.: TDC determination in IC engines based on the thermodynamic analysis of the Temperature-Entropy diagram, SAE International, Warrendale, PA, Tech. Rep. 1999-01-1489, May 1999. [Online]. Available: http://papers.sae.org/1999-01-1489

[3] HOHENBERG,G., KILLMANN,I.: Basic findings from mesaurement of the combustion process, XIX FISITA Congress, Melbourne, 1982.

[4] JANKOV,R.: Mathematical modeling of current-dynamic processes and operating characteristics of diesel engines, quasi-stationary models, Part I, basics, Scientific Book, Belgrade in 1984.

[5] CVETIĆ,M.: Modeling the flow of combustion based on current injection diesel engine with direct injection, doctoral dissertation, Faculty of Mechanical Engineering, University of Belgrade, Belgrade in 2000 .

[6] PETROVIĆ,S., JANKOV,R., TOMIĆ,M., FILIPI,Z., PUŠONJA,M., JOVANOVIĆ,Z.: Modeling of combustion in the CI engine, monographs, Faculty of Mechanical Engineering, Belgrade in 2005.

[7] AVL BOOST-Engine Cycle Simulation Version 3.0, Software to simulate the working process of the engine, ALV Graz, Austria, 1998.

[8] Dvigateli vnutrennogo sgoranija, Teorija porševih i kombinnirovannih dvigatelej, Mašinostroenije, Moskva, 1983.

[9] ŠTAVLJANIN,M: The research of injection process of multy-cylinder diesel engines in unsteady work conditions of fuel injection system, doctoral dissertation, Faculty of Mechanical Engineering, University of Belgrade, Belgrade in 2007.

[10] BULATOVIĆ.Ž.: Identification of the parameters of the equivalent dynamic-torsion system based on the changing flow of the angular speed of the crankshaft, Doctoral dissertation, Faculty of Mechanical Engineering, University of Belgrade, Belgrade in February 2015.

[11] KUESTER,J.L., MIZE,J.H.: Optimization Techniques with Fortran, McGraw-Hill book company, 1973.

[12] BULATOVIĆ,Ž., KNEŽEVIĆ,D., MILIĆ,M.: Practical Research of the Angle of Thermodynamic Losses when Indicating Pressure in the Cylinder Diesel Engine, Scientific Tehnical Review, ISSN 1820-0206, 2015, Vol.65, No.4, pp.46-54.

\section{Uticaj poremećaja u procesu ubrizgavanja goriva na radne procese u cilindrima dizel-motora}

\footnotetext{
Neujednačenost radnih procesa u cilindrima dizel-motora se može desiti iz više razloga. Dva najuticajnija faktora na ovu pojavu, a koji se odnose na poremećaje u procesu ubrizgavanja goriva, su: poremećaji u pogledu trenutnog položaja (ugla obrtanja) kolenastog vratila kada započinje ubrizgavanje goriva u nekom od cilindara, tzv. ugao predubrizgavanja, i poremećaji u količini goriva koja se isporučuje pojedinim cilindrima tokom jednog radnog ciklusa, tzv. ciklusna količina goriva. Navedeni poremećaji su daleko izraženiji kod klasičnih, mehaničkih sistema za ubrizgavanje goriva (pumpa visokog
} 
pritiska, pumpa-brizgač, itd.), i vrlo često se ne mogu preduprediti pri vanmotorskim ispitivanjima i podešavanjima sistema ubrizgavanja goriva. Simulacija opisanih poremaćaja u realnim uslovima rada dizel-motora, i proširivanje saznanja o njihovom pojedinačnom i zajedničkom uticaju na radne procese u cilindrima, nije nimalo jednostavna. Međutim, danas postoje komercijalni programi koji imaju ugrađene module zasnovane na proverenim jednačinama termodinamike, teorije sagorevanja i teorije strujanja, koje omogućavaju da se ova simulacija izvrši primenom računara. Jedan od takvih programa je program BOOST AVL. Rezultati simulacija dobijeni primenom ovog i sličnih programa mogu biti i pouzdaniji od simulacija u realnim uslovima rada motora, pošto je kod mehaničkih sistema ubrizgavanja goriva, vrlo teško kvantifikovati stepen poremećaja koji se želi simulirati. Dobijeni rezultati mogu biti iskorišćeni za razvijanje metoda identifikacije uticaja opisanih poremećaja na srednji indikatorski pritisak svakog cilindra, pa i celog motora, tačniju procenu mehaničkih gubitaka (stepena mehaničke korisnosti), itd.

Ključne reči : motor SUS, dizel motor, cilindar motora, radni proces, ubrizgavanje goriva, ugao predubrizgavanja, merenje pritiska.

\title{
Воздействие разрушения в процессе впрыска топлива на рабочие процессы в цилиндрах дизельного двигателя
}

\begin{abstract}
Несовместимость рабочих процессов в цилиндрах дизельных двигателей может произойти по нескольким причинам. Два из наиболее влиятельных факторов на это явление, которые связаны с нарушениями в процессе впрыска топлива, являются: нарушения с точки зрения текущего положения (угол поворота) коленчатого вала, при котором начинается впрыск топлива в одном из цилиндров, так называемого угла предварительного впрыска, а также нарушения в количестве топлива, подаваемого в отдельные цилиндры в течение одного рабочего цикла, так называемое количество циклов топлива. Эти разрушения гораздо более выражены в классических, механических системах для впрыска топлива (насос высокого давления, насос-форсунки и т.д.), и очень часто не могут быть предотвращены в тестированиях вне двигателя и в настройках системы для впрыска топлива. Не совсем просты моделирование описанных расстройств в реальных условиях эксплуатации дизельных двигателей, а также и расширение знаний об их индивидуальном и совместном воздействиях на рабочие процессы в цилиндрах. Тем не менее, сегодня существуют коммерческие программы, которые имеют встроенные модули, основанные на проверенных уравнениях термодинамики, теории горения и теории потока, что позволяет осуществлять это моделирование с помощью компьютера. Одной из таких программ является программа AVL BOOST. Результаты моделирования, полученные с использованием этой и подобных программ могут быть более надёжными, чем моделирования в реальных условиях работы двигателя, так как у механических систем для впрыска топлива очень трудно определить степень нарушения подлежащего имитации. Полученные результаты могут быть использованы для разработки методов определения воздействия описанных разрушений на среднее указывающее давление каждого цилиндра, а также и всего двигателя, и для более точной оценки механических потерь (степени механической полезности) и т.д.
\end{abstract}

Ключевые слова: двигатель внутреннего сгорания, дизельный двигатель, цилиндр двигателя, рабочий процесс, впрыск топлива, угол предварительного впрыска, измерение давления.

\section{Effet des perturbations dans le processus de l'injection de carburant sur le processus de travail chez les cylindres des moteurs diesel}

\begin{abstract}
L'inégalité des processus de travail dans les cylindres des moteurs diesel peut être causée par plusieurs raisons. Les deux facteurs influençant le plus à ce phénomène et qui se rapportent aux perturbations dans le processus de l'injection de carburant sont: perturbation de la position actuelle (angle de rotation) de vilebrequin lorsque l'injection de carburant commence dans les cylindres dite angle de pré - injection et les perturbations liées à la quantité de carburant fournie aux cylindres pendant un cycle de travail, appelée quantité cycle de carburant. Les perturbations citées sont beaucoup plus prononcées chez les systèmes mécaniques classiques pour l'injection de carburant (pompe haute pression, pompe injecteur, etc.) et souvent ne peuvent pas être évitées pendant les tests hors moteurs et des réglages des systèmes pour l'injection de carburant. La simulation des perturbations décrites dans les conditions réelles de travail de moteur et l'enrichissement des connaissances sur leur singulière ou commune influence aux processus de travail dans les cylindres n'est point simple. Il y a des programmes commerciaux qui possèdent les modules intégrés basés sur les équations vérifiées de thermodynamique, de théorie de combustion et de l'écoulement qui permettent la simulation par ordinateur. Un tel programme est le programme BOOST AVL. Les résultats obtenus des simulations par ce programme ou par d'autres programmes similaires peuvent être plus fiables que la simulation dans les conditions réelles de travail de moteur car il est très difficile de quantifier le degré de perturbation à simuler chez les systèmes mécaniques d'injection de carburant. Les résultats obtenus peuvent s'utiliser pour développer les méthodes d'identification de l'effet des perturbations décrites sur la pression moyenne indicatrice pour chaque cylindre et le moteur entier aussi, ensuite pour l'évaluation précise des pertes mécaniques (degré d'utilité mécanique) etc.
\end{abstract}

